\title{
Detection of CRYPTOSPORIDIUM OOCYSTS In GREen MUSSELS (PERNA VIRIDIS) FROM SHELL-FISH MARKETS OF THAILAND
}

\author{
SRISUPHANUNT M.*, SAKSIRISAMPANT W.** $\&$ KARANIS P.***,*****
}

\section{Summary:}

Mussels filter large volumes of water and can concentrate pathogenic organisms, which may act as potential vehicles of transmission to the consumer. A survey study was carried out to investigate the presence of Cryptosporidium protozoan parasites in green mussels (Perna viridis), the smussles pecies most destined for consumption in Thailand. In total, 56 samples were examined from Bangkok ( $n=24)$ and Samut Prakan ( $=32$ ) a wholesale shell-fish markets located at the mouth of the Chao Phraya River. The market for green mussels was closed to the mussel culture placed along the coastal line and this localization may have significant economical impact if the mussels' cultures are found contaminated. Cryptosporidium spp. oocysts were detected by the immunofluorescence antibody method (IFA) in $12.5 \%$ of the samples examined. The detection of Cryptosporidium oocysts in green mussels' population of Samut Prakan was higher (15.6\%) than in Bangkok market (8.3\%). These differences in positive samples from the two locations may be caused by physical, ecological and anthropogenic conditions. This could relay to different contamination levels of marine water by Cryptosporidium oocysts and consequently to contamination of harvested shellfish populations. The results demonstrate that the Cryptosporidium spp. oocysts were found indigenous in mussels from the coastal line of Thailand, indicating that mussels may act as a reservoir of Cryptosporidium foodborne infections for humans.

KEY WORDS : Cryptosporidium, green mussels, Thailand.

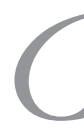

Tryptosporidium species are protozoan parasites that are increasingly recognized as important pathogens and widespread cause of enteric disease in humans and in many common wildlife (Smith \& Rose, 1998). The severity of infection can vary greatly depending on the species of Cryptosporidium, the specific isolate or genotype of the parasite, and on the immune status of the host. Whilst there are several species of Cryptosporidium which have the potential to infect humans, the most important are C. bominis

\footnotetext{
* Faculty of Public Health, Mahidol University, Bangkok 10400, Thailand.

*** Faculty of Medicine, Chulalongkorn University, Bangkok 10330, Thailand.

**** University of Cologne, Medical School, Anatomy II, Medical and Molecular Parasitology Laboratory, Cologne, Germany.

**:**: National Research Center for Protozoan Diseases, Obihiro University of Agriculture and Veterinary Medicine, Inada-Cho, Obihiro, Hokkaido 080-8555, Japan.

Correspondence: Mayuna Srisuphanunt

E-mail: mayunaph@yahoo.com; phmayuna@staff2.mahidol.ac.th
}

Résumé : DÉTECTION D'OOCYSTES DE CRYPTOSPORIDIUM CHEZ LA MOULE VERTE (PERNA VIRIDIS) SUR DES MARCHÉS DE POISSONS EN THAILANDE

Les moules filtrent un important volume d'eau et peuvent héberger des pathogènes potentiellement transmissibles aux consommateurs. Une étude a été menée afin de détecter la presence de Cryptosporidium, protozoaires parasites de la moule verte (Perna viridis), espèce la plus consommée en Thaillande. 56 prélèvements ont été réalisés à Bangkok ( $n=24)$ et à Samut Prakan $(n=32)$, un marché de vente en gros de coquillages et poissons, situé à l'embouchure de la rivière Chao Phraya, sachant qu'une contamination des moules aurait un important impact économique sur ce marché qui est proche des parcs d'élevage situés le long de la côte. Des oocystes de Cryptosporidium spp. ont été détectés par immunofluorescence (IFA) chez 12,5\% des prélèvements, avec un pourcentage d'infestation plus élevé à Samut Prakan (15,6\%) qu'à Bangkok (8,3 \%) qui pourrait s'expliquer par des conditions physiques, écologiques et anthropologiques différentes. Les résultats montrent principalement que des oocystes de Cryptosporidium spp. sont présents dans les moules de la côte thaïlandaise, lesquelles peuvent être considérées comme un réservoir de cryptosporidiose humaine d'origine alimentaire.

MOTS CLÉS : Cryptosporidium, moule verte, Thaillande. (human infections) and C. parvum (a zoonotic infection). The infections tend to be self-limiting in the immunocompetent host, but is particularly serious for immunocompromised people because there is no cure for the disease (Fayer et al., 1997). Cryptosporidia are transmitted via the faecal-oral route primarily by consumption of contaminated food and water. Several epidemics of cryptosporidiosis associated to foodstuffs and water supplies have been reported. The potential for contamination with the transmissive stages of C.parvum is gaining increasing attention (Griffiths, 1998; Girdwood \& Smith, 1999; Rose \& Slifko, 1999; Robertson \& Gjerde, 2000; Nichols \& Smith, 2001). Coasts and rivers can be contaminated by Cryptosporidium oocysts if these water environments are polluted by anthropogenic and livestock fecal discharges (Fayer et al., 2003).

The mussels are filter feeders that feed on phytoplankton, zooplankton and suspended organic materials. They are eaten by fish, crustaceans, seastars, 
octopuses and humans (NIPMIS, 2007). Molluscan shellfish harvesting areas can become contaminated by the oocysts the infectious stage of the parasite. Humans are therefore at risk of infection either by consumption of shellfish, or by taking part in recreational activities in these areas. The presence of Cryptosporidium oocysts in mussels has been reported in European countries (Gomez-Bautista et al., 2000; Lowery et al., 2001; Gómez-Couso et al., 2003; Gómez-Couso et al., 2004; MacRae et al., 2005; Li et al., 2006), USA (Graczyk et al., 1999; Miller et al., 2005), and Canada (Graczyk et al., 2001). The detection of these parasites in mussels is of concern due to the potential cryptosporidiosis risk of consuming raw or light-cooked seafood. Evidence for Cryptosporidium transmission via shellfish consumption in Thailand, even in Asian, is not elucidated yet.

Perna viridis or green mussel is native to South-East Asia and harvested in the Indo-Pacific region as a food source due to its fast growth. It is a common indigenous saltwater bivalve mollusc, which is the major species destined for human consumption. The species is commercially important to Thailand and is indigenous along the costal area of the gulf of Thailand, particular at the mouth of the Chao Phraya River. The mussels live in waters that are $11-32{ }^{\circ} \mathrm{C}$ with a wide-ranging salinity of about $18-33$ ppt (NIPMIS, 2007). They can survive in soft, muddy bottom waters of about two to eight metres, but grows fastest at two meters below the surface. Growth is especially rapid in high salinity waters with high concentrations of phytoplankton. The species can also tolerate a range of salinities and turbid waters (GSMFCR, 2007). The objective of this study was to investigate the occurrence of Cryptosporidium oocysts in green mussels native to the mouth of the Chao Phraya River especially in areas used for seafood supply and consumption because of its public health significance.

\section{MATERIALS AND METHODS}

\section{GEOGRAPHY AND SAMPLE COLLECTION}

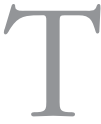
The Kingdom of Thailand lies in the heart of Southeast Asia, making it a natural gateway to Indochina, Myanmar, and Southern China. The coastal line of Thailand located on the bank of Chao Phraya River, near Bangkok to the south of the country has a tropical climate. The survey was conducted at the site to mussel native culture placed along the mouth of the Chao Phraya River in the coastal areas of Thailand from November 2006 to February, 2007. A total of 56 samples were collected from Bangkok and Samut Prakan shell-fish markets. These are large wholesale markets and have significant impact on fresh water

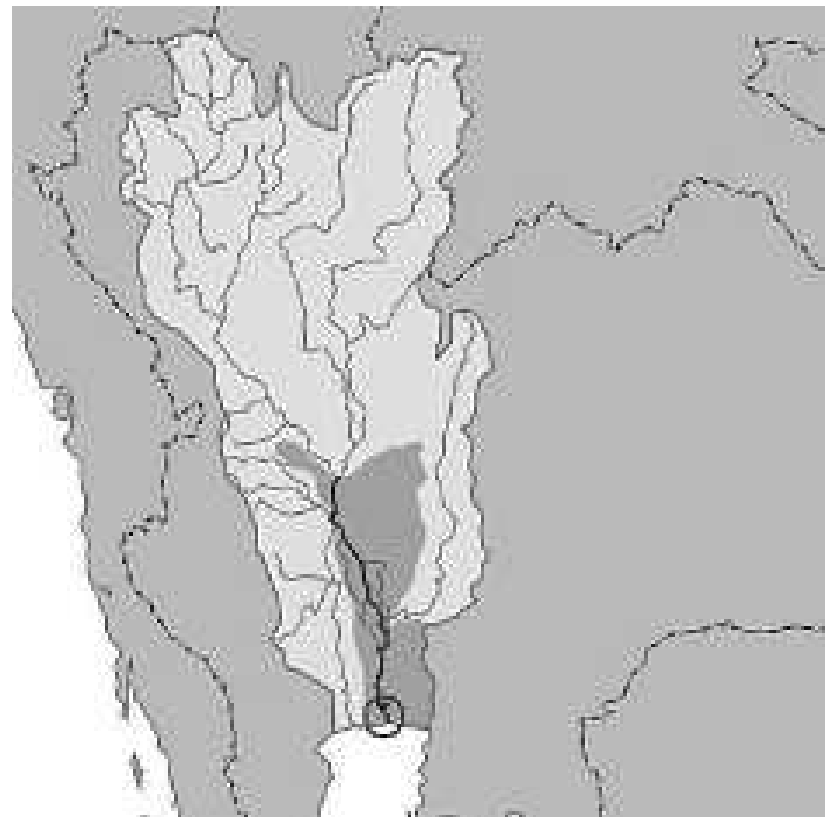

Fig 1. - Map demonstrating the settings for samples collection in this study. The area in the circle is the mouth of Chao Praya River, Thailand. The study settings are along the banks in two provinces, Bangkok and Samut Prakan (circle).

aquatic food supplies. The samples were collected from different sites of the markets, 24 samples from Bangkok and 32 from Samut Prakan (20 kilometers south of Bangkok) (Fig. 1). Both areas count to the economical significant account for aquatic animals producing areas.

Each sample consisted of the pool gills and gastrointestinal tracts from seven to eight mussels of medium valve size $80 \mathrm{~mm} \times 40 \mathrm{~mm}( \pm 6.7 \times 3.2)$. An aliquot of each individual sample was stored before the constitution of the pool for further Cryptosporidium species identification. The pooled samples were homogenized in PBS (0.04 M, pH 7.2) using a Molinex homogenizer (Japan). The resulting homogenates of each pool were then passed through a sieve (mesh size 45 and $150 \mu \mathrm{m}$ ), suspended in PBS/diethyl ether $(2: 1, \mathrm{v} / \mathrm{v})$, and concentrated by centrifugation at $1,250 \times \mathrm{g}$, for $5 \mathrm{~min}$, at $4^{\circ} \mathrm{C}$. The sediments from each pool were examined for the presence of Cryptosporidium oocysts.

\section{DETECTION OF CRYPTOSPORIDIUM OOCYSTS}

A direct immunofluorescence antibodies (IFA) assay was applied to detect Cryptosporidium oocysts in the sediments obtained. Samples were placed on glass microscope slides, air dried and stained with a specific monoclonal antibody against an epitope of Cryptosporidium oocyst wall, and fluorescein isothiocyanate (FITC) labelling as described by the manufacturer Monofluo ${ }^{\circledR}$ Kit Cryptosporidium (Sanofi Diagnostics Pasteur, France). The oocysts were identified under an 
FITC filter using fluorescence microscopy (OLYMPUS, Model BX 51), according to the criteria proposed by Graczyk et al. (1998), i.e. brilliant green fluorescence, correct shape and size of the FITC-labelled objects with clearly visible oocyst wall.

\section{RESULTS}

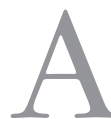

total of 56 samples were have been investigated. All of Cryptosporidium oocysts identified positive samples were round in shape with an average mean of $4.9 \mu \mathrm{m}$ in size $(4.2-6.0 \pm 0.3)$. Cryptosporidium oocysts were detected by IFA assay in $12.5 \%$ of the total samples examined. Five out of 32 samples (15.6\%) were Cryptosporidium positive in green mussels from Samut Prakan whereas two out of 24 samples (8.3\%) from Bangkok market were positive for Cryptosporidium oocysts (Table I).

\begin{tabular}{|c|c|c|c|}
\hline Origin & $\begin{array}{c}\text { No. of } \\
\text { samples } \\
\text { analysed }\end{array}$ & $\begin{array}{c}\text { No. of } \\
\text { positive } \\
\text { samples }\end{array}$ & $\begin{array}{c}\% \text { of } \\
\text { positive } \\
\text { samples }\end{array}$ \\
\hline \multicolumn{4}{|l|}{ Samples from Bangkok (24) } \\
\hline . Phrannok market & 20 & 2 & 8.3 \\
\hline Sathorn BKK fish market & 4 & 0 & 0 \\
\hline \multicolumn{3}{|l|}{ Samples from Samut Prakan (32) } & 8.3 \\
\hline . Mueang Samut Prakan & 10 & 2 & 20.0 \\
\hline . Phra Samut Chedi & 11 & 2 & 18.2 \\
\hline Bang Bo & 6 & 1 & 16.7 \\
\hline \multicolumn{4}{|l|}{$\begin{array}{l}\text { Bang Namphueng floating } \\
\text { market }\end{array}$} \\
\hline Total & 32 & 5 & 15.6 \\
\hline Total & 56 & 7 & 12.5 \\
\hline
\end{tabular}

Table I. - Cryptosporidium contamination in mussels from Bangkok and Samut Prakan markets located on the bank of the Chao Praya River.

\section{DISCUSSION}

M ost marine molluscan bivalve shellfish feed on suspended phytoplankton which is trapped from water pumped across the gills by ciliary action (Robertson, 2007). Pathogenic microorganisms in the water may be filtered by the gills during feeding, and become concentrated in the digestive glands/ tract. The potential for marine bivalve shellfish to act as transmission vehicles for outbreaks of protozoan infections in humans has been noted before (Melo et al., 2006). The occurrence of Cryptosporidium oocysts in seafood therefore represents an important public health concern and surveys of Cryptosporidium oocysts will be useful surveillance measures to protect the public health.

Several researchers reported on this system of surveillance (Graczyk et al., 1998; Gomez-Bautista et al.,
2000; Graczyk et al., 2001; Lowery et al., 2001; Giangaspero et al., 2005; Miller et al., 2005; Gómez-Couso et al., 2006; Melo et al., 2006; Robertson, 2007). For example, Miller et al. (2005) studied clams (Corbicula fluminea) as bioindicator of fecal contamination with Cryptosporidium spp. in freshwater ecosystems in California. The work reported that oocyst dose and clam collection times were significant predictors for detecting C. parvum oocysts in clams. Gómez-Couso et al. (2006) determined the levels of detection by IFA technique for Cryptosporidium oocysts in mussels experimentally contaminated with a theoretical number of oocysts. In the naturally contaminated samples of Cryptosporidium oocysts, this paper reported $31.1 \%$ of contamination and only C. parvum has been found. In another study, infective C. parvum oocysts were detected in mussels and cockle from a shellfish-producing region that account for the majority of European shellfish production (Gomez-Bautista et al., 2000). All these data suggested that mussels and cockles could act as a reservoir of C. parvum infections to humans (GomezBautista et al., 2000; Graczyk et al., 1998; Graczyk et al., 2001; Lowery et al., 2001).

In the present work, the green mussels (Perna viridis) native to the mouth of the Chao Phraya River have been examined for the presence of Cryptosporidium oocysts. Up to $12.5 \%$ of the samples analyzed contained Cryptosporidium oocysts. This rate is considerable high from a public health perspective and similar to those levels cited in previous reports (Gomez-Bautista et al., 2000; Lowery et al., 2001; Giangaspero et al., 2005). Moreover, water analysis in the area where the mussel samples were collected in the Chao Phraya River was also conducted. The contamination of river water by Cryptosporidium oocysts has been documented (data unpublished), thereby confirms the possible sources of contamination in the area of harvested shellfish and consequently enhances the potential risk of infection to humans.

Apparently, several conditions may affect contamination of marine waters by Cryptosporidium oocysts, such as heavy rains, storms and floods which wash oocysts from the land, cause sewage overflow and increase urban and agricultural runoff. Mussel samples were collected from locations with considerable contamination levels of anthropogenic and live stock fecal discharges. The detection rate of Cryptosporidium spp. oocysts in green mussels from Samut Prakan was higher than from the Bangkok area. Samut Prakan is significant fresh water aquatic industry land with high human population of fisherman communities, the density of grazing ruminants, aquatic farm practices and high frequently rainfall and runoff of Cryptosporidium oocysts into water may play a significant role to the contamination (Walker \& Stedinger, 1999). Moreover, Samut Prakan is located closer to outfalls of river flo- 
wing than in Bangkok; consequently the physical hydrogeoraphy of river mouths, estuaries and adjacent shores can greatly affect the distribution of Cryptosporidium oocysts in the area. We assume that risk assessment differences in positivity from the two locations may be caused from ecological and anthropogenic influences, resulting in different contamination level of marine water by oocysts and contamination of harvested shellfish populations.

Although the Cryptosporidium species identification and viability test would be necessary among these isolates, morphological characteristics of oocysts were consistent with those of $C$. parvum. The size range of oocysts of various species other than $C$. parvum are almost larger (O'Donoghue, 1995). Species differentiation of Cryptosporidium by IFA method is not possible because of no species-specific monoclonal antibodies are available. Since present results were obtained from pooled mussels for each site and period of time, this limitation does not exclude variations in oocyst content between individual mussels. Identification by molecular analysis is recommended to confirm the Cryptosporidium species and genotypes.

Nevertheless the present results demonstrate for the first time in Thailand that the Cryptosporidium oocysts were found indigenous in mussel from the coastal line of the country, where they may act as a reservoir of Cryptosporidium infections for humans. Furthermore, it is also possible to use this mussel species in a surveillance system for the presence Cryptosporidium oocysts and outbreaks prevention. The epidemiological links and a seasonal variation between the occurrence of Cryptosporidium oocysts in green mussels (Perna viridis) and infections to humans need further investigations.

\section{CONCLUSION}

$\mathrm{R}$ esults demonstrate for the first time in the region of Thailand near the mouth of the Chao Phraya River indigenous green mussels (Perna viridis) brought to market may act as a reservoir of Cryptosporidium infection for humans. The detection of the oocysts represents a potential public health problem. Additional sampling is recommended to confirm results by molecular tools and infectivity experiments. Should Cryptosporidium oocysts continue to be observed in the affected mussels populations, then appropriate actions should be taken to protect the public health.

\section{ACKNOWLEDGEMENTS}

W

e would like to thank the Public Utilities Board, Singapore for providing Monofluo ${ }^{\circledR}$ Kit Cryptosporidium (Sanofi Diagnostics Pas- teur, France) for parasite IFA testing. This work was partial supported by DAAD, Germany, the Commission on Higher Education and Thailand Research Fund and for publication by the China Medical Board (CMB), Faculty of Public Health, Mahidol University.

\section{REFERENCES}

FAyer R., SpeER C.A. \& Dubey J.P. The general biology of Cryptosporidium, in: Cryptosporidium and Cryptosporidiosis. Fayer R. (ed.), CRC Press, Boca Raton, FL, 1997, 1-42.

Fayer R., Trout J.M., Lewis E.J., Santin M., Zhou L., Lal A.A. \& XIAO L. Contamination of Atlantic coast commercial shellfish with Cryptosporidium. Parasitology Research, 2003, 89 (2), 141-145.

FAYeR R., Dubey JP. \& Lindsay D.S. Zoonotic protozoa: from land to sea. Trends in Parasitology, 2004, 20 (11), 531-536.

Giangaspero A., Molini U., Iorio R., Traversa D., Paoletti B. \& Giansante C. Cryptosporidium parvum oocysts in seawater clams (Chameleagallina) in Italy. Preventive Veterinary Medicine, 2005, 69 (3-4), 203-312.

Girdwood R.W.A. \& SMith H.V. Cryptosporidium, in: Encyclopaedia of food microbiology, in: Robinson R., Batt C. \& Patel P. (eds.), Academic Press, London, 1999, 487-497.

Gomez-Bautista M., Ortega-Mora L.M., Tabares E., LopezRoDAs V. \& Costas E. Detection of infectious Cryptosporidium parvum oocysts in mussels (Mytilus galloprovincialis) and cockles (Cerastoderma edule). Applied and Environmental Microbiology, 2000, 66 (5), 1866-1870.

Gómez-Couso H., Freire-Santos F., Martínez-Urtaza J., GarcíaMartín O. \& AREs-MazÁs M.E. Contamination of bivalve molluscs by Cryptosporidium oocysts: the need for new quality control standards. International Journal of Food Microbiology, 2003, 87 (1-2), 97-105.

Gómez-Couso H., Freire-Santos F., Amar C.F., Grant K.A., Williamson K., Ares-Mazás M.E. \& McLauchlin J. Detection of Cryptosporidium and Giardia in molluscan shellfish by multiplexed nested-PCR. International Journal of Food Microbiology, 2004, 91 (3), 279-288.

Gómez-Couso H., Méndez-Hermida F. \& Ares-MazÁs E. Levels of detection of Cryptosporidium oocysts in mussels (Mytilus galloprovincialis) by IFA and PCR methods. Veterinary Parasitology, 2006, 141 (1-2), 60-65.

Graczyk T.K., Farley C.A., Fayer R., LeWIs E.J. \& Trout J.M. Detection of Cryptosporidium oocysts and Giardia cysts in the tissues of eastern oysters (Crassostrea virginica) carrying principal oyster infectious disease. Journal of Parasitology, 1998, 84, 1039-1042.

Graczyk T.K., Fayer R., Lewis E.J., Trout J.M. \& Farley C.A. Cryptosporidium oocysts in Bent mussels (Ischadium recurvum) in the Chesapeake Bay. Parasitology Research, 1999, 85 (7), 518-521.

Graczyk T.K., Marcogliese D.J., Delafontaine Y., DaSilva A.J., Mhagami-Ruwende B. \& Pieniazek N.J.. Cryptosporidium parvum oocysts in zebra mussels (Dreissena polymorpha): evidence from the St Lawrence River. Parasitology Research, 2001, 87, 231-234. 
GRIFFITHS J.K. Human cryptosporidiosis: epidemiology, transmission, treatment and diagnosis. Advances in Parasito$\log$, 1998, 40, 37-85.

GSMFCR. Perna viridis (Linnaeus, 1758). Gulf States Marine Fisheries Commission Retrieved on 2007-09-25.

li X., Guyot K., Dei-Cas E., Mallard J.P., Ballet J.J. \& BrasSEUR P. Cryptosporidium oocysts in mussels (Mytilus edulis) from Normandy (France). International Journal of Food Microbiology, 2006, 108 (3), 321-325.

Lowery C.J., Nugent P., Moore J.E., Millar B.C., Xiru X. \& DoOley J.S. PCR-IMS detection and molecular typing of Cryptosporidium parvum recovered from a recreational river source and an associated mussel (Mytilus edulis) bed in Northern Ireland. Epidemiology and Infection, 2001, $127,545-553$.

MacRae M., Hamilton C., Strachan N.J., Wright S. \& Ogden I.D. The detection of Cryptosporidium parvum and Escherichia coli $\mathrm{O} 157$ in UK bivalve shellfish. Journal of Microbiological Methods, 2005, 60 (3), 395-401.

Melo P.C., Teodosio J., Reis J., Duarte A., Costa J.C. \& FonSECA I.P. Cryptosporidium spp. in freshwater bivalves in Portugal. Journal of Eukaryotic Microbiology, 2006, 53 (Suppl. 1), S28-S29.

Miller W.A., Atwill E.R., Gardner I.A., Miller M.A., Fritz H.M., Hedrick R.P., Melli A.C., Barnes N.M. \& Conrad P.A. Clams (Corbicula fluminea) as bioindicators of fecal contamination with Cryptosporidium and Giardia spp. in freshwater ecosystems in California. International Journal for Parasitology, 2005, 35 (6), 673-684.

Miller W.A., Miller M.A., Gardner I.A., Atwill E.R., Harris M., Ames J., Jessup D., Melli A., Paradies D., Worcester K., Olin P., Barnes N. \& Conrad P.A. New genotypes and factors associated with Cryptosporidium detection in mussels (Mytilus spp.) along the California coast. International Journal for Parasitology, 2005, 35 (10), 1103-1013.

Nichols R.A.B. \& SмITH H.V. Parasites: Cryptosporidium, Giardia and Cyclospora as foodborne pathogens, in: Foodborne pathogens. Hazards, risk analysis and control. Blackburn C.W. \& McClure P.J. (Eds.), Woodhead Publishing Ltd., Cambridge, UK, 2001), 453-478.

NIPMIS. Asian Green Mussel. National Introduced Pest Marine Information System. Retrieved on 2007-09-25.

O'Donoghue P.J. Cryptosporidium and Cryptosporidiosis in man and animals. International Journal for Parasitology, 1995, 85, 525-530.

ROBERTSON L.J. \& GJERDE B. Isolation and enumeration of Giardia cysts, Cryptosporidium oocysts, and Ascaris eggs from fruits and vegetables. Journal of Food Protection, 2000, 63 (6), 775-877.

RoberTSOn L.J. The potential for marine bivalve shellfish to act as transmission vehicles for outbreaks of protozoan infections in humans: a review. International Journal of Food Microbiology, 2007, 120 (3), 201-216.

Rose J.B. \& Slifko T.R. Giardia, Cryptosporidium, and Cyclospora and their impact on foods: a review. Journal of Food Protection, 1999, 62 (9), 1059-1070.

SMith H.V. \& Rose J.B. Waterborne cryptosporidiosis: current status. Parasitology Today, 1998, 14 (1), 14-22.
WALKer F.R. \& STEDinger J.R. Fate and transport model of Cryptosporidium. Journal of Environmental Engineering, 1999, 125, 325-333.

Reçu le 25 mars 2008 Accepté le 25 mars 2009 